\title{
Penyusunan Laporan Keuangan Pondok Pesantren Darussalam Mekar Agung Tahun 2019 Berdasarkan Pedoman Akuntansi Pesantren
}

\author{
Miftahul Rifa'i ${ }^{1}$, Arini Wildaniyati ${ }^{2}$ \\ ${ }^{1}$ Mahasiswa Program Studi Akuntansi, Fakultas Ekonomi, Universitas Merdeka Madiun \\ ${ }^{1}$ E-mail: miftahulrifai19@gmail.com \\ ${ }^{2}$ Program Studi Akuntansi, Fakultas Ekonomi, Universitas Merdeka Madiun \\ ${ }^{2}$ E-mail: arini@unmer-madiun.ac.id
}

\begin{abstract}
The Darussalam Mekar Agung Islamic Boarding School is a non-profit organization that is not profit-oriented, but there must be good and correct financial reporting. The main source of income for this Islamic boarding school comes from the contribution of the students. Thus, there must be transparency and accountability in the financial reporting. Islamic boarding schools must be able to produce financial reports in accordance with standards so that these financial reports can be understood by all parties. The purpose of this study is to determine the preparation of financial statements in accordance with the Islamic Boarding School Accounting Guidelines.

The research method used is a qualitative method with a descriptive approach. The location of this research is in the Darussalam Mekar Agung Islamic Boarding School, Pucanganom Village, Kebonsari District, Madiun Regency. Data collection obtained by means of observation, interviews, and documentation. The data obtained are primary data and secondary data. Primary data was obtained from Mr. Fahrul Amiruddin as the treasurer of the cottage. And secondary data obtained from the financial reports of Islamic boarding schools.

The results of this study indicate that the Darussalam Mekar Agung Islamic Boarding School has not implemented the Islamic Boarding School Accounting Guidelines in financial reporting. The recording is still relatively simple. The treasurer only records income and expenses without making final calculations to adjust income and expenses (debit and credit).
\end{abstract}

Keywords : preparation, financial reports, Islamic boarding school accounting guidelines

\section{PENDAhUluAN}

Pondok Pesantren merupakan organisasi nirlaba yang tidak mencari profit namun perlu adanya pencatatan dana keluar dan dana masuk agar jelas dan transparan. Diperlukan suatu pedoman yang dapat menjadi acuan dalam menyusun laporan keuangan di dalam pesantren. Maka dari itu Bank Indonesia (BI) dan Ikatan Akuntan Indonesia (IAI) mengeluarkan standar baru yang mengatur penyusunan laporan keuangan pondok pesantren yaitu pedoman akuntansi pondok pesantren. Dengan ada peraturan baru tersebut dapat menjadi suatu landasan bagi pondok pesantren untuk membenahi dan menyempurnakan laporan keuangan di dalam pesantren tersebut, agar laporan keuangan di dalam pesantren bisa lebih dimengerti dan dapat dipertanggungjawabkan kebenarannya. Serta laporan keuangan bagi Pondok Pesantren sesuai dengan standar akuntansi yang berlaku umum. Di dalam Pedoman Akuntansi Pesantren terdapat 4 macam laporan keuangan yaitu laporan posisi keuangan , laporan aktivitas, laporan arus kas , dan catatan atas laporan arus kas.(Pedoman Akuntansi Pesantren, 2018)

Di dalam Undang-undang Pesantren bab V menerangkan tentang pendanaan yang pada pasal 48 berisi mengenai peran pemerintah dalam membantu pendanaan penyelenggaraan pesantren melalui APBN sesuai dengan kemampuan keuangan negara. Dengan hal ini semakin menjelaskan pentingnya suatu laporan keuangan yang terperinci di dalam pesantren yang sesuai dengan pedoman akuntansi pesantren yang telah dikeluarkan oleh IAI dan yang didasari dengan asas pengelolaan keuangan yaitu transparansi dan akuntabilitas. Di dalam Pedoman Akuntansi Pesantren penyusunan laporan keuangannya meliputi laporan aktivitas, laporan arus kas, laporan posisi keuangan, dan catatan atas laporan keuangan.

Perkembangan jaman yang makin modern mengharuskan pesantren mampu memperathankan eksistensinya sebagai sarana pendidikan dan penyiaran islam dan diharapkan pesantren dapat semakin adaptif dengan perkembangan kemajuan jaman.bisa dilihat saat ini pesantren sudah menunjukkan kemajuannya dengan melahirkan lulusan-lulusan terbaik yang mampu memberikan kontribusi bagi kemajuan Indonesia. Saat ini juga dalam Undang-undang nomor 18 tentang Pesantren pasal 18-19 menyebutkan bahwa lulusan pesantren jalur non formal diakui sama dengan pendidikan formal pada jenjang tertentu setelah lulus ujian, sehingga bisa melanjutkan ke pendidikan formal yang lebih tinggi. Dengan adanya hal ini semakin membuktikan bahwa lulusan pesantren mampu bersaing dengan dengan lulusan sekolah formal. Akan tetapi masih ada hal-hal yang perlu dibenahi lagi di dalam pondok pesantren yaitu tentang permasalahan sumber daya manusia yang mengelola keuangan pondok pesantren ( Pedoman Akuntansi Pesantren, 2018). 
Akuntabilitas di Pondok Pesantren Darussalam Mekar Agung, terutama dalam hal transparasi keuangannya masih belum maksimal. Transparasi keuangan pondok pesantren hanya sebatas pengasuh, ketua pondok, dan bendahara pondok saja yang mengetahuinya dan tidak di publikasikan kepada seluruh santri.

Akan tetapi, meskipun Pondok Pesantren Darussalam Mekar Agung termasuk pondok pesantren terbesar di Kabupaten Madiun, pondok pesantren ini memiliki kendala dalam menyusun laporan keuangan, yaitu belum sesuai dengan Pedoman Akuntansi Pesantren (PAP) yang diterbitkan oleh Bank Indonesia (BI) dan Ikatan Akuntan Indonesia (IAI). Pondok pesantren ini hanya mencatat pemasukan dan pengeluaran saja tanpa melakukan perhitungan akhir untuk menyesuaikan pemasukan dan pengeluaran tersebut. Hal ini terjadi karena kurangnya sumber daya manusia yang mengelola keuangan pondok pesantren.

Landasan Teori

1. Laporan Keuangan

Laporan keuangan merupakan sesuatu yang penting dalam sebuah perusahaan. Menurut Kasmir (2008: 7), "laporan keuangan adalah laporan yang menunjukkan kondisi keuangan perusahaan pada saat ini atau dalam suatu periode tertentu".

2. Pedoman Akuntansi Pesantren

Pedoman Akuntansi Pesantren adalah panduan akuntansi yang tidak mengikat untuk pondok pesantren dalam menyusun laporan keuangan yang sesuai dengan standar akuntansi keuangan yang berlaku umum di Indonesia. Pedoman ini diterapkan untuk yayasan pondok pesantren dan tidak diterapkan untuk badan usaha yang berupa badan hukum tersendiri, seperti perseroan terbatas yang dimiliki oleh yayasan pondok pesantren

3. Penyajian Laporan Keuangan Pondok Pesantren Menurut Pedoman Akuntansi Pesantren

Dalam Pedoman Akuntansi Pesantren sudah dijelaskan mengenai tujuan laporan keuangan yaitu:

"Memberikan informasi tentang posisi keuangan, kinerja, arus kas dan informasi lainnya yang bermanfaat bagi pengguna laporan keuangan dalam rangka membuat keputusan ekonomi dan bentuk pertanggung jawaban pengurus yayasan pondok pesantren atas penggunaan sumber daya yang dipercayakan kepadanya."

Berdasarkan Uraian di atas, maka dibuatlah kerangka pemikiran sebagai berikut:

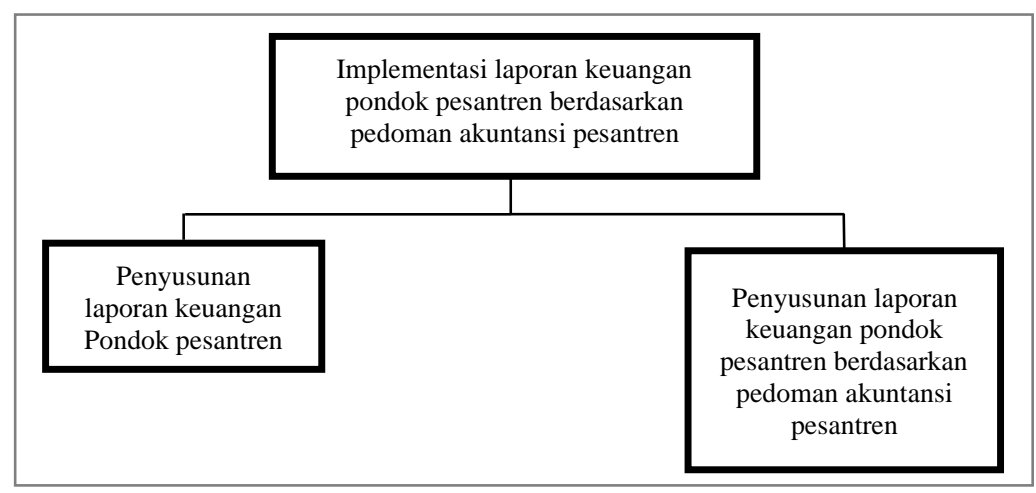

\section{METODE PENELITIAN}

Jenis penelitian yang digunakan untuk menganalis laporan keuangan di Pondok Pesantren Darussalam Mekar Agung adalah penelitian deskriptif yang berfungsi untuk mengetahui gambaran dari objek penelitian yang berkaitan dengan penyusunan laporan keuangan Pondok Pesantren Darussalam Mekar Agung tahun 2019 berdasarkan Pedoman Akuntansi Pesantren.

Jenis data dalam penelitian ini adalah data sekunder, karena data yang digunakan adalah laporan keuangan Pondok Pesantren Darussalam Mekar Agung tahun 2019. Sedangkan sumber data dalam penelitian ini adalah data primer, karena diperoleh secara langsung dari sumber asli (tidak melalui media perantara). Analisis yang dipakai dalam penelitian ini adalah Teknik analisis data kualitatif.

\section{HASIL DAN PEMBAHASAN}

Penelitian ini bertujuan untuk menyusun rancangan laporan keuangan berdasarkan Pedoman Akuntansi Pesantren yang mulai efektif tahun 2018. Selama ini, laporan keuangan yang disusun Pondok Pesantren Darussalam Mekar Agung hanya selisih antara pemasukan dan pengeluaran. Akuntabilitas juga penting diterapkan di pondok pesantren disamping penyusunan keuangan yang sesuai standar. Menurut Mardiasmo (2009),

"Akuntabilitas Publik adalah kewajiban pihak pemegang amanah (agent) untuk memberikan pertanggung jawaban, menyajikan, melaporkan, dan mengungkapkan segala aktivitas dan kegiatan yang menjadi tanggung jawabnya kepada pihak pemberi amanah (principal) yang memilki hak dan kewenangan untuk meminta pertanggungjawaban tersebut".

Laporan keuangan yang dibuat hanya cukup dilaporkan kepada pengasuh. Akan tetapi, ada hal penting yang perlu diperbaiki pada system pelaporan keuangan pondok pesantren yaitu sistem penyusunan yang sesuai dengan Pedoman Akuntansi Pesantren 
supaya laporan keuangan yang disusun sesuai dengan standar. Untuk membuat penyusunan laporan keuangan yang sesuai standar, maka diperlukan tahapan-tahapan sebagai berikut:

1. Reduksi Data

a. Mengidentifikasi transaksi-transaksi yang ada di Pondok Pesantren Darussalam Mekar Agung.

b. Mengidentifikasi catatan-catatan keuangan yang dimiliki oleh Pondok Pesantren Darussalam Mekar Agung.

2. Penyajian Data

a. Menyusun kode rekening dan daftar nama akun.

b. Memasukan data-data keuangan Pondok Pesantren Darussalam Mekar Agung.

c. Menyusun laporan keuangan Pondok Pesantren Darussalam Mekar agung.

3. Kesimpulan

a. Sesuai atau tidaknya laporan keuangan Pondok Pesantren Darussalam Mekar Agung dengan Pedoman Akuntansi Pesantren

Berdasarkan beberapa tahapan di atas, maka ada beberapa data yang dibutuhkan dalam penyusunan laporan keuangan ini yang diperoleh dengan cara-cara sebagai berikut:

1. Wawancara yang dilakukan yaitu dengan pengurus bendahara pondok pesantren. Tujuan dari wawancara ini adalah untuk mengetahui aktivitas transaksi yang terjadi pada Pondok Pesantren Darussalam Mekar Agung. Selain itu, untuk menggali informasi yang dibutuhkan mengenai akuntansi aset, liabilitas dan aset neto.

2. Observasi yang dilakukan bertujuan untuk melihat secara langsung aktivitas apa yang terjadi, apakah sesuai dengan apa yang disampaikan atau tidak.

3. Dokumentasi yang diperlukan yaitu mengenai laporan keuangan yang disusun oleh Pondok Pesantren Darussalam Mekar Agung baik itu bulanan dan tahunan 2019. Hal ini sebagai dasar penyesuaian laporan keuangan berdasarkan Pedoman Akuntansi Pesantren.

Berikut adalah penyusunan laporan keuangan Pondok Pesantren Darussalam Mekar Agung tahun 2019 berdasarkan Pedoman Akuntansi Pesantren:

1. Laporan Posisi Keuangan

Tabel I

Laporan Posisi Keuangan Pondok Pesantren

Darussalam Mekar Agung

31 Desember 2019

\begin{tabular}{|c|c|c|c|}
\hline \multicolumn{4}{|c|}{$\begin{array}{c}\text { Yayasan Pondok Pesantren Darussalam Mekar Agung } \\
\text { Laporan Posisi Keuangan } \\
\text { 31 Desember } 2019\end{array}$} \\
\hline \multicolumn{2}{|l|}{ Aset } & \multicolumn{2}{|l|}{ Liabilitas } \\
\hline \multicolumn{2}{|l|}{ Aset Lancar } & \multicolumn{2}{|l|}{ Liabilitas Jangka Pendek } \\
\hline Kas dan Setara Kas & Rp. 252.847.050 & Pendapatan Diterima Di Muka & Rp. - \\
\hline Piutang Usaha & Rp. - & Utang Jangka Pendek & Rp. - \\
\hline Persediaan & Rp. - & Liabilitas Jangka Pendek Lain & Rp. - \\
\hline Biaya Dibayar Di Muka & Rp. - & Jumlah & Rp. - \\
\hline Perlengkapan & Rp. 3.200 .000 & \multicolumn{2}{|l|}{ Liabilitas Jangka Panjang } \\
\hline Jumlah & Rp. 256.047.050 & Utang Jangka Panjang & Rp. - \\
\hline \multicolumn{2}{|l|}{ Aset Tidak Lancar } & Liabilitas Imbalan Kerja & Rp. - \\
\hline Investasi Pada Entitas Lain & Rp. - & Liabilitas Jangka Panjang Lain & Rp. - \\
\hline Property Investasi & Rp. - & Jumlah & Rp. - \\
\hline Tanah & Rp. 935.000 .000 & \multicolumn{2}{|l|}{ Aset Neto } \\
\hline Bangunan & Rp. 2.171.800.000 & Aset Neto Tidak Terikat & -Rp. 51.147.250 \\
\hline Akumulasi Penyusutan Bangunan & (Rp. 54.295.000) & Aset Neto Terikat Temporer & Rp. 217.585.000 \\
\hline Peralatan dan Inventaris & Rp. 113.620.000 & Aset Neto Terikat Permanen & Rp. - \\
\hline $\begin{array}{l}\text { Akumulasi Penyusutan Peralatan dan } \\
\text { Inventaris }\end{array}$ & (Rp. 19.006.250) & Modal & Rp. 3.236.728.050 \\
\hline Aset Tidak Berwujud & Rp. - & & \\
\hline Aset Tidak Lancar Lain & Rp. - & & \\
\hline Jumlah & Rp. 3.147.118.750 & Jumlah Aset Neto & Rp. 3.403.165.800 \\
\hline Total Aset & Rp. 3.403.165.800 & Total Liabilitas dan Aset Neto & Rp. 3.403.165.800 \\
\hline
\end{tabular}


2. Laporan Aktivitas

\begin{tabular}{|c|c|}
\hline $\begin{array}{r}\text { Tabel II } \\
\text { Laporan Aktivitas Pond } \\
\text { Darussalam Mekar } \\
\text { 31 Desember } 2\end{array}$ & $\begin{array}{l}\text { Pesantren } \\
\text { Agung } \\
19\end{array}$ \\
\hline $\begin{array}{r}\text { Yayasan Pondok Pesantren Daruss } \\
\text { Laporan Aktivita } \\
\text { Untuk Tahun Yang Berakhir pada }\end{array}$ & $\begin{array}{l}\text { am Mekar Agung } \\
1 \text { Desember } 2019\end{array}$ \\
\hline Nama akun & 2019 \\
\hline Perubahan Aset Neto Tidak Terikat & \\
\hline Penghasilan Tidak Terikat & \\
\hline Kontribusi santri & Rp. 155.667.000 \\
\hline Jumlah & Rp. 155.667 .000 \\
\hline Beban Tidak Terikat & \\
\hline Beban Kegiatan Hari Raya & Rp. 313.000 \\
\hline Beban Kegiatan 17 Agustus & Rp. 767.000 \\
\hline Beban Kesehatan & Rp. 2.464.800 \\
\hline Beban Konsumsi & Rp. 5.632.000 \\
\hline Beban Pendidikan & Rp. 616.500 \\
\hline Beban Upah Kerja & Rp. 3.250 .000 \\
\hline Beban Administrasi dan Umum & Rp. 5.091.850 \\
\hline Beban Listrik dan Telepon & Rp. 52.972.850 \\
\hline Beban Akomodasi & Rp. 4.505 .000 \\
\hline Beban Reparasi dan Pemeliharaan & Rp. 7.294.000 \\
\hline Beban Pembangunan & Rp. 8.530.000 \\
\hline Beban Incidental & Rp. 4.935 .000 \\
\hline Beban Perlengkapan & Rp. 37.141 .000 \\
\hline Beban Penyusutan Bangunan & Rp. 54.295.000 \\
\hline $\begin{array}{l}\text { Beban Penyusutan Peralatan dan } \\
\text { Inventaris }\end{array}$ & Rp. 19.006.250 \\
\hline Kenaikan (Penurunan) & -Rp. 51.147.250 \\
\hline Saldo Awal & \\
\hline Saldo Akhir & -Rp. 51.147.250 \\
\hline Perubahan Aset Neto Terikat Tempor & \\
\hline Pendapatan & Rp. 644.427 .000 \\
\hline Beban & Rp. 426.842 .000 \\
\hline Surplus & Rp. 217.585.000 \\
\hline Kenaikan (Penurunan) & Rp. 217.585.000 \\
\hline Saldo Awal & \\
\hline Saldo Akhir & Rp. 217.585.000 \\
\hline Aset Neto Pada Awal Tahun & \\
\hline Aset Neto Pada Akhir Tahun & Rp. 166.437.750 \\
\hline
\end{tabular}

\section{Tabel III}

Laporan Arus Kas Pondok Pesantren Darussalam Mekar Agung

31 Desember 2019

\begin{tabular}{|l|l|}
\hline \multicolumn{2}{|c|}{$\begin{array}{c}\text { Yayasan Pondok Pesantren Darussalam Mekar Agung } \\
\text { Laporan Arus Kas } \\
\text { Untuk Tahun Yang Berakhir pada 31 Desember 2019 }\end{array}$} \\
\hline ARUS KAS OPERASI & Rp. 166.437 .750 \\
\hline Rekonsiliasi Perubahan Aset Neto Menjadi Kas Neto & \\
\hline Perubahan Aset Neto & Rp. 73.301 .250 \\
\hline Penyesuaian: & \\
\hline Penyusutan & \\
\hline Kenaikan Piutang Usaha & \\
\hline Kenaikan Persediaan & \\
\hline Penurunan Biaya Dibayar Di Muka &
\end{tabular}




\begin{tabular}{|l|l|}
\hline Kenaikan Pendapatan Diterima Di Muka & \multicolumn{2}{|l|}{} \\
\hline Jumlah Kas Neto Diterima Dari Aktivitas Operasi & Rp. 239.739.000 \\
\hline ARUS KAS INVESTASI & Rp. 5.045.000 \\
\hline Pembelian Aset Tidak Lancar & $($ Rp. 5.045.000) \\
\hline Jumlah Kas Neto Dikeluarkan Dari Aktivitas Investasi & \\
\hline ARUS KAS PENDANAAN & \\
\hline Pembayaran Utang Jangka Panjang & \\
\hline Jumlah Kas Neto Dikeluarkan Dari Aktivitas Pendanaan & Rp. 234.694.000 \\
\hline Kenaikan (Penurunan) & Rp. 18.153.050 \\
\hline Saldo Awal & Rp. 252.847.050 \\
\hline Saldo Akhir & \\
\hline
\end{tabular}

4. Catatan Atas Laporan Keuangan

\section{Tabel IV \\ Catatan Atas Laporan Keuangan Pondok Pesantren Darussalam Mekar Agung \\ 31 Desember 2019}

\begin{tabular}{|c|c|}
\hline $\begin{array}{c}\text { Yayasan Pondok Pesantren Darussalam Mekar Agung } \\
\text { Catatan Atas Laporan Keuangan } \\
\text { Untuk Tahun Yang Berakhir pada } 31 \text { Desember } 2019\end{array}$ \\
\hline
\end{tabular}

a. Selayang Pandang

Pondok Pesantren "Darussalam Mekar Agung" adalah salah satu dari sekian Pondok Pesantren yang ada di Kabupaten Madiun. Berdiri sejak tahun 1982 M / 1402 H yang didirikan oleh Al Maghfurlah KH. Muhammad Thohir Besyari, tepatnya di Dusun Kepuh Beluk, Desa Pucanganom, Kecamatan Kebonsari, Kabupaten Madiun dengan Akte Notaris Anisah Sri Wahyuni, SH.N nomor 17/2009 dan SK Menteri Hukum dan HAM nomor AHU-582.AH.01.04.tahun.2009. Pondok Pesantren ini menggunakan metode salafiyah yang menganut faham "AHLUSSUNNAH WAL JAMA'AH" melestarikan hal-hal lama yang baik dan mengembangkan hal-hal baru yang lebih baik dan bermanfaat, serta menekankan pada pendidikan Akhlak Salafussholih dan Kholafussholih. Metode ini di terapkan di Pondok Pesantren "Darussalam Mekar Agung" dalam bentuk adanya pendidikan formal yang mengajarkan ilmu-ilmu umum atau hal-hal yang baik sesuai dengan tuntutan hidup di era globalisasi, dan juga pendidikan Non Formal yang berupa Madrasah Diniyah yang khusus mengajarkan ilmu-ilmu agama islam dengan pengkajian pada kitab-kitab kuning. Selain itu juga ada bentuk pendidikan berupa kursus, diklat, ketrampilan dan lain-lain yang sekiranya di perlukan oleh santri sebagai bekal hidupnya kelak.

Dengan demikian santri-santri Pondok Pesantren "Darussalam Mekar Agung" dapat mempelajari disiplin ilmu secara utuh dalam arti tidak hanya mempelajari ilmu-ilmu agama tetapi juga mempelajari ilmu-ilmu yang bersifat umum, demi terwujudnya tujuan jangka pendek keselamatan kebahagiaan di dunia dan tujuan jangka panjang keselamatan dan kebahagiaan abadi di akherat kelak.

b. Ikhtisar Kebijakan Akuntansi

Berikut ini merupakan pokok-pokok kebijakan akuntansi yang diterapkan oleh Pondok Pesantren Darussalam Mekar Agung dalam menyusun keuangan:

1) Penyajian Laporan Keuangan

Laporan keuangan Pondok Pesantren Darussalam Mekar Agung disusun sesuai Pedoman Akuntansi Pesantren per 2018. Laporan keuangan yang disusun terdiri atas laporan posisi keuangan, laporan aktivitas, laporan arus kas, dan catatan atas laporan keuangan.

2) Dasar Penyusunan Laporan Keuangan

Pencatatan laporan keuangan Pondok Pesantren Darussalam Mekar Agung ini disajikan secara tahunan berdasarkan kalender masehi. Laporan keuangan disusun atas dasar akrual dengan menggunakan konsep nilai historis, kecuali dimana standar akuntansi mengharuskan pengkuran nilai wajar.

Laporan arus kas disusun dengan metode langsung dan menyajikan perubahan dalam kas dan setara kas dari aktivitas operasi, investasi, dan pendanaan.

Mata uang yang digunakan dalam laporan keuangan ini adalah mata uang Rupiah yang merupakan mata uang fungsional.

3) Kas dan Setara Kas

Kas dan setara kas mencangkup kas kecil

4) Persediaan

Metode perhitungan yang digunakan adalah metode perpetual

5) Aset Tetap

Aset tetap berupa tanah tidak disusutkan.

Aset tetap selain tanah dicatat sebesar biaya perolehannya dan dikurangi dengan akumulasi penyusutan.

Metode yang digunakan dalam penyusutan adalah metode garis lurus yang berdasarkan estimasi masa manfaat dari aset-aset tersebut.

6) Penghasilan dan Beban

Penghasilan dan beban Pondok Pesantren Darussalam Mekar Agung dibagi menjadi dua yaitu: 


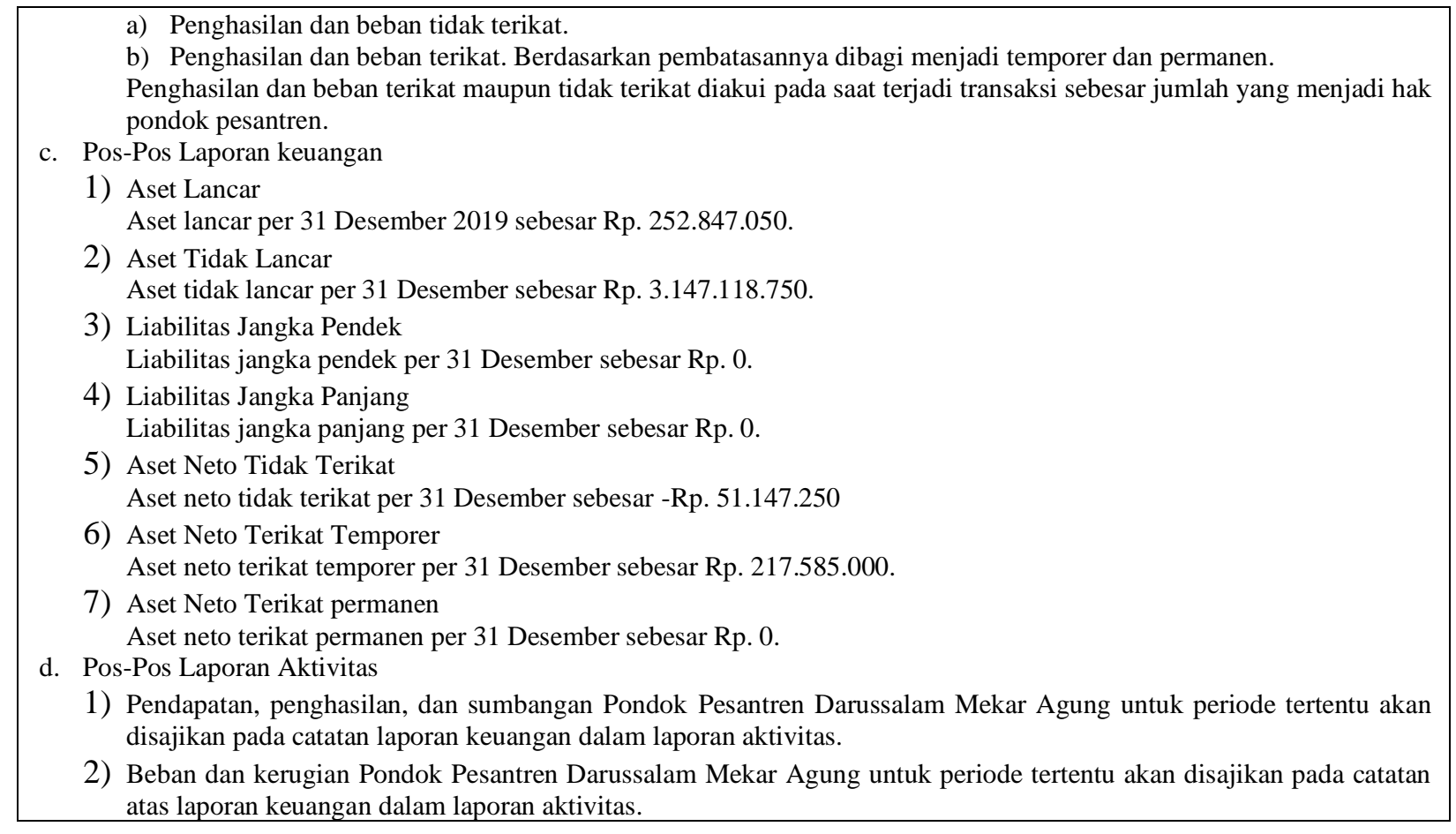

\section{KESIMPULAN}

Berdasarkan hasil penelitian dan pembahasan yang telah diuraikan di atas tentang Implementasi Laporan Keuangan Pondok

Pesantren Darussalam Mekar Agung Berdasarkan Pedoman Akuntansi Pesantren, maka dapat ditarik kesimpulan sebagai berikut:

1. Pondok Pesantren Darussalam Mekar Agung belum mengetahui dan menerapkan Pedoman Akuntansi Pesantren ketika membuat laporan keuangan.

2. Pencatatan laporan keuangan yang diterapkan Pondok Pesantren Darussalam Mekar Agung masih tergolong sederhana. Bendahara pondok hanya mencatat transaksi pemasukan dan pengeluaran kas dan kemudian pada akhir bulan seluruh transaksi direkap dan dilaporkan pada pengasuh pondok pesantren. Proses pencatatanpun tanpa melakukan perhitungan akhir untuk menyesuaikan pemasukan (debet) dan pengeluaran (kredit).

3. Laporan keuangan Pondok Pesantren Darussalam Mekar Agung tidak dipublikasikan pada semua santri yang ada di pondok pesantren, hanya bendahara, lurah pondok, dan pengasuh yang boleh mengetahui laporan keuangan tersebut. Sehingga Pondok Pesantren Darussalam Mekar Agung belum melakukan transparasi dan akuntabilitas.

4. Pedoman Akuntansi Pesantren sangat mungkin bisa diterapkan dalam penyusunan laporan keuangan yang ada di Pondok Pesantren Darussalam Mekar Agung, dikarenakan laporan keuangan yang disusun di atas sudah sesuai dengan standar Pedoman Akuntansi Pesantren. Sehingga, laporan keuangan tersebut dapat dibaca dan dipahami oleh seluruh elemen pondok pesantren, baik santri, pengurus, dan pengasuh.

Berdasarkan hasil penelitian dan pembahasan yang telah diuraikan, maka terdapat beberapa saran yang diberikan yaitu:

1. Bagi bendahara pondok pesantren diharapkan untuk mempelajari Pedoman Akuntansi Pesantren agar dapat membuat laporan keuangan yang sesuai dengan standar yang telah ditetapkan.

2. Bagi bendahara pondok pesantren diharapkan juga untuk mengembangkan rekomendasi-rekomendasi yang telah diberikan sesuai dengan kebutuhan yang diperlukan, seperti membuat aplikasi komputer agar pencatatan laporan keuangan lebih mudah dan efisien.

3. Diharapkan bagi pondok pesantren untuk melakukan transparasi dan akuntabilitas agar laporan keuangan untuk ke depannya memiliki nilai tambah.

\section{DAFTAR PUSTAKA}

Afif, Rizandhi Faizzal. 2017. Analisis System Pengelolaan Keuangan di Pondok Pesantren Terhadap Penguatan Manajemen Keuangan (Studi Kasus Pada Pesantren Luhur Al Husna Surabaya). Skripsi. Fakultas Ekonomi dan Bisnis Universitas Jember, Jember.

Aldiansyah \& Linda Lambey. 2017. Penerapan PSAK No.45 Revisi Tahun 2015 Pada Yayasan Madrasah Ibtidaiyyah Baitul Makmur Kota Kotamobagu. Journal Accountabillity. V.6, No.1, 92-102.

Dhofier, Zamakhsyari. 2011. Tradisi Pesantren. Jakarta: LP3ES.

Fatih, M. 2015. Implementasi Penyusunan Laporan Keuangan Pada Lembaga Nirlaba Yayasan Berdasarkan Psak No.45 (Studi Pada Yayasan Pesantren Global Tarbiyyatul Arifin). Skripsi. Fakultas Ekonomi Universitas Islam Negeri Maulana Malik Ibrahim, Malang.

Ikatan Akuntan Indonesia. 1998. Pelaporan Keuangan Organisasi Nirlaba. Pernyataan Standar Akuntansi Keuangan No.45.

Ikatan Akuntan Indonesia. 2009. Standar Akuntansi Keuangan Entitas Tanpa Akuntabilitas Publik. Jakarta: Dewan Standar Akuntansi Keuangan. 
Ikatan Akuntansi Indonesia. 2018. Pedoman Akuntansi Pesantren. Jakarta: Bank Indonesia.

Jusup, Al Haryono. 2016. Dasar-Dasar Akuntansi Jilid 1. Yogyakarta. Bagian Penerbitan Sekolah Tinggi Ilmu Ekonomi YKPN.

Kasmir. 2009. Analisis Laporan Keuangan. Jakara: Rajawali Pers.

Mardiasmo. 2009. Akuntansi Sektor Publik. Yogyakarta: Andi.

Moleong, L.J. 2017. Metodologi Penelitian Kualitatif Edisi Revisi. Bandung: PT. Remaja Rosdakarya.

Shihab, M. Quraish. 2002. Tafsir Al-Misbah: Pesan, Kesan dan Keserasian al-Qur'an. Jakarta. Lentera Hati.

Sugiyono. 2015. Metode Penelitian Kuantitatif, Kualitatif, dan R\&. Bandung: Alfabeta.

Syarifuddin, Luthfi. 2020. Penyusunan Laporan Keuangan Berdasarkan Pedoman Akuntansi Pesantren Anwarul Huda Kota Malang. Skripsi. Fakultas Ekonomi Universitas Islam Negeri Maulana Malik Ibrahim, Malang.

Triyuwono, Iwan. 2011. Mengangkat “Sing Liyan” Untuk Formulasi Nilai Tambah Syariah. https://jamal.ub.ac.id/index.php/jamal/article/view/137 [diakses pada tanggal 24 Desember jam 20:31]

Undang-Undang Republik Indonesia Nomor 20 Tahun 2003. Tentang Sistem Pendidikan Nasional. Jakarta.

Undang-Undang Republik Indonesia Nomor 18 Tahun 2019. Tentang Pesantren. Jakarta.

Zamroni, Muh. Farih. 2018. Penyusunan Laporan Keuangan Dalam Perspektif PSAK No.45 Di Yayasan Darul Mustaghitsin. Skripsi. Fakultas Ekonomi Universitas Islam Negeri Maulana Malik Ibrahim, Malang. 